\title{
REFLECTIONS ON PRIVATE REPOSSESSION, PUBLIC POLICY AND THE CONSTITUTION
}

\author{
MARK G. Yudof†
}

\section{INTRODUCTION}

In the preface to The Immoralist, André Gide defends his failure to pass judgment on the hero of his novel: "I do not indeed claim that neutrality (I was going to say 'indecision') is the certain mark of a great mind; but I believe that many great minds have been very loath to . . conclude-and that to state a problem clearly is not to suppose it solved in advance."1 If this is the test of intellectual greatness, many of those writing in the commercial law field have passed with flying colors. In the complex world of law and economics, of formulas and regression analyses, it is far easier to convey one's confusions than to assert definite legal and policy conclusions. Alas, however, I must join the ranks of the lesser minds; for this essay is anything but neutral. To the question whether private repossession under the Uniform Commercial Code violates the due process clause of the fourteenth amendment, I answer decidedly in the affirmative: ${ }^{2}$

In recent Supreme Court and lower federal court decisions, the judiciary, to paraphrase the description of one commentator, ${ }^{3}$ has run wild by legislating out of existence various prejudgment remedies-garnishment, cognovit notes, replevin and other similar devices available to creditors. ${ }^{4}$ The

† Assistant Professor of Law, University of Texas at Austin. B.A. 1965, J.D. 1968, University of Pennsylvania. Member, Pennsylvania Bar.

${ }^{1}$ A. Gide, The Immoralist vii-viii (1962).

${ }^{2} \mathrm{~A}$ number of other authors maintain the opposite position. See, e.g., Burke \& Reber, State Artion, Congressional Power and Creditors' Rights: An Essay on the Fourteenth Amendment, 47 S. CAl.. L. Rev. 1 (1973); Mentschikoff, Peaceful Repossession Under the Uniform Commercial Code: A Constitutional and Economic Analysis, 14 WM. \& Mary L. Rev. 767 (1973); White, The Abolition of Self-Help Repossession: The Poor Pay Even More, 1973 Wis. L. Rrv. 503 (1973). On the other hand, Professors Clark and Landers share my conclusion, see Clark \& Landers, Sniadach, Fuentes and Beyond: The Creditor Meets the Constitution, 59 VA. L. REv. 355 (1973).

${ }^{3}$ See Siberfieid, Legislative and Judicial Developments in 1972, 89 BANking L.J. 1059, 1077 (1972).

4 See, e.g., Fuentes v. Shevin, 407 U.S. 67 (1972); Sniadach v. Family Finance Corp., 395 U.S. 337 (1969); Hall v. Garson, 430 F.2d 430 (5th Cir. 1970); Aaron v. Clark, 342 F. Supp. 898 (N.D. Ga. 1972); Adams v. Egley, 338 F. Supp. 614 (S.D. Cal. 1972), rev'd sub nom. Adams v. Southern Cal. First Nat'l Bank, 492 F.2d 324 (9th Cir. 1974); 
constitutional defect in each of these cases was the failure of the state to provide notice and the opportunity for a hearing before a neutral official prior to the seizure of the debtor's property. Most involved consumer transactions where the bargaining power of the debtor was slight, and therefore the creditor's assertion of contractual waiver of the constitutional right to notice and hearing by the debtor was viewed as insubstantial. The next round of the debate over prejudgment remedies, which has received extensive attention among commentators ${ }^{5}$ and lower federal courts, ${ }^{6}$ is whether private repossession should also be declared unconstitutional. The relevant portion of the Uniform Commercial Code is section 9-503: "Unless otherwise agreed, a secured party has on default the right to take possession of the collateral. In taking possession a secured party may proceed without judicial process if this can be done without breach of the peace or may proceed by action. ..." Of the many courts that have addressed this issue, only a few have responded affirmatively. ${ }^{7}$ A majority of the commentators seem similarly

Laprease v. Raymours Furniture Co., 315 F. Supp. 716 (N.D.N.Y. 1970); Klim v. Jones, 315 F. Supp. 109 (N.D. Cal. 1970); Randone v. Appellate Dep't of the Superior Ct., 5 Cal. 3d 536, 488 P.2d 13, 96 Cal. Rptr. 709 (1971), cert. denied, 407 U.S. 924 (1972); Jones Press, Inc. v. Motor Travel Services, Inc., 286 Minn. 205, 176 N.W.2d 87 (1970); cases cited note 7 infra. But see, e.g., Brunswick Corp. v. J \& P, Inc., 424 F.2d 100 (10th Cir. 1970); Oller v. Bank of America, 342 F. Supp. 21 (N.D. Cal. 1972); cases cited note 7 infra. See generally Clark \& Landers, supra note 2; Countryman, The Bill of Rights and the Bill Collector, 15 Ariz. L. Rev. 521 (1973).

${ }^{5}$ See, e.g., Burke \& Reber, supra note 2; Clark, Default, Repossession, Foreclosure, and Deficiency: A Journey to the Underworld and a Proposed Salvation, 51 ORE. L. Rev. 302 (1972); Clark \& Landers, supra note 2; Countryman, supra note 4; Dauer \& Gilhool, The Economics of Constitutionalized Repossession: A Critique for Professor Johnson, and a Partial Reply, $47 \mathrm{~S}$. Cal. L. Rev. 116 (1973); Dunham, Due Process and Commercial Law, 1972 Sup. CT. Rev. 135: Johnson, Denial of Self-Help Repossession: An Economic Analysis, 47 S. CAL. L. REv. 82 (1973) [hereinafter cited as Johnson, Denial of Self-Help Repossession]; Johnson, $A$ Response to Dauer and Gilhool: $A$ Defense of Self-Help Repossession, id. 151 [hereinafter cited as Johnson, $A$ Response]; Martin, Secured Transactions, 19 WAirve L. REv. 593 (1973); McCall, The Past as Prologue: A History of the Right to Repossess, 47 S. CAL. L. Rev. 58 (1973); Mentschikoff, supra note 2; Neth, Repossession of Consumer Goods: Due Process for the Consumer, What's Due for the Creditor, 24 CASE W. REs. L. REv. 7 (1972); White, supra note 2; Comment, 50 DEN. L.J. 261 (1973).

${ }^{6}$ See cases cited note 7 infra.

7 Holding $\S 9-503$ unconstitutional, e.g.: Boland v. Essex County Bank \& Trust Co., Civil No. 72-3299-G (D. Mass., Aug. 15, 1973), summarized at 42 U.S.L.W. 2116 (1973); Michel v. Rex-Noreco, Inc., 12 UCC REP. SERV. 543 (D. Vt. 1972); Gibbs v. Titelman, 4 CCH SEC. TR. GuIDE II 52,241 (E.D. Pa. 1973); Adams v. Egley, 338 F. Supp. 614 (S.D. Cal. 1972), rev'd sub nom. Adams v. Southern Cal. First Nat'l Bank, 492 F.2d 324 (9th Cir., 1974); Chrysler Credit Corp. v. Dinitz, 11 UCC REP. SERv. 627 (N.Y. Civ. Ct. 1972); cases cited in Burke \& Reber, supra note 2 , at 8 n.490.

Holding \& 9-503 constitutional, e.g.: Adams v. Southern Cal. First Nat'l Bank, 492 F.2d 324 (9th Cir. 1974); Mayhugh v. Bill Allen Chevrolet, 4 CCH SEC. TR. Guide If 52, 251 (W.D. Mo. 1973); Kinch v. Chrysler Credit Corp., 4 CCH SEC. TR. Guide If 52,248 (E.D. Tenn. 1973); Turner v. Impala Motors, Civil No. C-73-50 (W.D. Tenn., June 15, 1973); Shirley v. State Nat'l Bank, Civil No. 15,319 (D. Conn., Apr. 2, 1973); Colvin v. Avco Fin'l Servs., Inc., 12 UCC REP. SERv. 25 (D. Utah 1973); Kirksey v. Theilig, 351 F. Supp. 727 (D. Colo. 1972); Pease v. Havelock Nat'l Bank, 351 F. Supp. 118 (D. Neb. 1972); Greene v. First Nat'l Exch. Bank, 348 F. Supp. 672 (W.D. Va. 1972); 
disposed, ${ }^{8}$ and with a fragile 4-3 majority in Fuentes $v$. Shevin, ${ }^{9}$ the leading Supreme Court case, these commentators may well turn out to be excellent prognosticators. But the arguments to the contrary are weighty, and this Article is devoted to their presentation.

\section{BACKG ROUND}

The recent attack on prejudgment remedies began in 1966 , nearly 100 years after the adoption of the fourteenth amendment, when Christine Sniadach decided that she could not live on only half of her sixty dollar per week salary. The Family Finance Company had instituted a garnishment action against Ms. Sniadach and her employer, seeking to garnish one half of her wages in order to satisfy a promissory note for $\$ 420$ which she had signed. Ms. Sniadach responded with the argument that the garnishment of her wages, without prior notice and judicial hearing, violated the due process clause of the fourteenth amendment. Ms. Sniadach lost at the hands of an unresponsive Wisconsin Supreme Court, ${ }^{10}$ but she received a considerably more hospitable reception from the United States Supreme Court. By a near unanimous vote, the Court declared the Wisconsin garnishment procedure unconstitutional. ${ }^{11}$ In the words of Mr. Justice Douglas, writing for seven members of the Court:

A prejudgment garnishment of the Wisconsin type is a taking which may impose tremendous hardship on wage earners with families to support. . . .

The leverage of the creditor on the wage earner is enormous. ...

The result is that a prejudgment garnishment of the Wisconsin type may as a practical matter drive a

McCormick v. First Nat'l Bank, 322 F. Supp. 604 (S.D. Fla. 1971); Northside Motors, Inc. v. Brinkley, 4 CCH SEC. TR. GuIDE I 52,185 (Fla. Sup. Ct. 1973); Brown v. United States Nat'l Bank, 96 Ore. Adv. Sheets 1667, 509 P.2d 442 (1973); Giglio v. Bank of Del., 12 UCC REP. SERv. 934 (Del. Ch. 1973); Messenger v. Sandy Motors, Inc., 4 CCH SEC. TR. GuIDE I 51,952 (N.J. Super. Ct. 1972); Yankwitt v. Franklin Nat'l Bank, 12 UCC REP. SERv. 1254 (N.Y. Dist. Ct. 1973); cases cited in Burke \& Reber, supra note 2, at 8 n.490.

${ }^{8}$ Of the commentators cited in note 5 supra, Professors Clark and Landers, Professors Dauer and Gilhool and Professor Countryman conclude that $\S 9-503$ is unconstitutional.

${ }^{9} 407$ U.S. 67 (1972). The Supreme Court has heard oral argument in Mitchell v. W.T. Grant Co., 263 La. 627, 269 So.2d 186 (1972), cert. granted, 93 S. Ct. 2276 (1973), which involves issues almost identical to those in Fuentes. See 42 U.S.L.W. 3345 (1973). This case should settle the controversy over the vitality of Fuentes.

10 Family Finance Corp. v. Sniadach, 37 Wis. 2d 163, 154 N.W.2d 259 (1967).

"Sniadach v. Family Finance Corp., 395 U.S. 337 (1969). For discussion of Sniadach, see, e.g., Clark \& Landers, supra note 2; Countryman, supra note 4; Kennedy, Due Process Limitations on Creditors' Remedies: Some Reflections on Sniadach v. Family Finance Corp., 19 AM. U.L. Rev. 158 (1970). 
wage-earning family to the wall. Where the taking of one's property is so obvious, it needs no extended argument to conclude that absent notice and a prior hearing ... this prejudgment garnishment procedure violates the fundamental principles of due process. ${ }^{12}$

Mr. Justice Harlan, responding both to the majority and to $\mathrm{Mr}$. Justice Black's dissent, concurred with characteristic eloquence:

[T] ]he Due Process Clause of the Fourteenth Amendment limits state action by norms of "fundamental fairness" whose content in any given instance is to be judicially derived not alone ... from the specifics of the Constitution, but also ... from concepts which are part of the Anglo-American legal heritage ....

... A Apart from special situations, ... I think that due process is afforded only by the kinds of "notice" and "hearing" which are aimed at establishing the validity, or at least the probable validity of the underlying claim against the alleged debtor before he can be deprived of his property or its unrestricted use. ${ }^{13}$

Sniadach proved to be a law professor's delight, a source of endless discussion and confusion both to the practicing bar and to law students. For while that decision's applicability to garnishment laws in most states was obvious, the scope of the opinion remained obscure. Was the decision applicable to wage assignments, which accomplished largely the same objective as wage garnishment but which involved, at least arguably, some additional measure of debtor consent? Both Justices Douglas and Harlan noted that summary. procedures were appropriate in some largely unspecified emergency circumstances. What were these circumstances? Was garnishment permissible for jurisdictional purposes? In order to prevent the debtor from fleeing the jurisdiction with the wages? Was Sniadach applicable to other types of prejudgment remedies? Cognovit notes? Replevin actions? Private repossessions? Seizures of all goods? Or were wages somehow special because necessary to the very survival of the family? If Sniadach were applicable to the retaking of goods, what constituted an emergency which would justify summary procedures under those circumstances? A threat of destruction or removal of the collateral? Most importantly, what constituted an adequate prior hearing? Did the decision require, as $\mathrm{Mr}$. Justice Harlan suggested, simply an opportunity to demonstrate

12395 U.S. at $340-42$ (footnote omitted).

${ }^{13}$ Id. at $342-43$. 
that the asserted claim was colorable or probable, or did it require a full-scale judicial hearing on the merits? In what fashion, if any, might a debtor waive his constitutional right to notice and hearing? As might be suspected, the lower federal courts differed sharply in their approaches to these post-Sniadach problems. ${ }^{14}$

In 1972, after a three year hiatus, the Supreme Court addressed itself to many of these issues. In Fuentes $v$. Shevin, ${ }^{15}$ it declared unconstitutional replevin statutes in Florida ${ }^{16}$ and Pennsylvania ${ }^{17}$ which allowed the seizure of goods without notice or hearing. In so doing, the Court expressly or by implication settled a number of critical issues. First, Sniadach was not applicable only to wages or to some extraordinarily vital classes of property. Fuentes involved the seizure of a stove, a stereo, a table, a bed and other similar items, and the Court expressly held that the fourteenth amendment was applicable to property generally and not only to so-called "necessities of life." 18 The Court, quite appropriately I think, eschewed reliance on so subjective a standard.

Second, the Court attempted to define in the narrowest of terms those emergency circumstances which would allow summary procedures. The Court opined that such circumstances must be "truly unusual" and strongly hinted that "private gain," in contrast to the fulfillment of some significant governmental interest, would never suffice. ${ }^{19}$ Third, Mr. Justice Stewart who wrote for the four man majority-Justices Rehnquist and Powell did not participate-stated that due process was applicable to even temporary deprivations of property; for under the Florida and Pennsylvania replevin statutes, the debtor could recover his property within three days of the seizure if he posted a bond for double the value of the goods seized. ${ }^{20}$ So long as the deprivation was not de minimis, notice and hearing were required, although the weight of the property interest was relevant to the form of notice and hearing that would be required.21 Fourth, without

${ }^{14}$ See, e.g., Reeves v. Motor Contract Co., 324 F. Supp. 1011 (N.D. Ga. 1971); Black Watch Farms, Inc. v. Dick, 323 F. Supp. 100 (D. Conn. 1971); First Nat'l Bank \& Trust Co. v. Pomona Mach. Co., 107 Ariz. 286, 486 P.2d 184 (1971).

15407 U.S. 67 (1972).

${ }^{16}$ Act of May 30, 1955, ch. 29,706, § 1, 1955 Fla. Laws 195 (repealed 1973); Act of Mar. 10, 1845, \$§ 4, 6, 7 (repealed 1973); Act of Feb. 2, 1861, ch. 1099, \& 1 (repealed 1973). (1967).

${ }^{17}$ Pa. Stat. Ann. tit. 12, § 1821 (1967); Pa. R. Civ. P. 1037(a), 1073, 1076, 1077

${ }^{18} 407$ U.S. at $88-90$.

${ }^{19}$ Id. at 90-92. But of. id. at 93 .

${ }^{20} \mathrm{Id}$. at $80-84$.

${ }^{21}$ Id. at 90 n.21. 
specifying coherent limits, the Court held that the nature of the prior hearing was largely a matter of legislative discretion. ${ }^{22}$ Fifth, the majority largely avoided the question of waiver of due process rights by noting that the.purported waiver in Fuentes did not clearly indicate that summary procedures were contemplated..$^{23}$ However, the Court reviewed with favor its earlier decision in D.H. Overmyer Co. v. Frick, ${ }^{24}$ which required that a due process waiver be "voluntarily, intelligently, and knowingly" made, ${ }^{25}$ and intimated strongly that this would rarely be the case in consumer transactions, where the inequality of bargaining power between the parties is legendary.

At the risk of oversimplification, the Fuentes decision appears to portend a revolution in creditor-debtor relations, a revolution which the Supreme Court is overseeing but not explaining. I say this for two reasons. First, the Supreme Court has adopted a rather intriguing definition of the property interest sufficient to trigger due process guarantees. In Sniadach, as in the typical eminent domain proceeding, there was no doubt as to who owned the property in question. The wages belonged to Ms. Sniadach who had earned them, and the dispute was over whether the creditor could claim those wages, without judicial approval, to satisfy another obligation. In a sense, the creditor was no more entitled to those wages than a merchant would be entitled to seize $\$ 500$ from a table top while attending a cocktail party given by his debtor. Or to put the matter in a different light, no more than an automobile purchaser is entitled to return his "lemon" and seize another car from his dealer's lot. In these cases, there is no conflict as to who owns the property in question, and it seems quite reasonable to require some judicial supervision, by way of notice and hearing, before the debtor is deprived of his property to satisfy a debt which he may contest. The situation in Fuentes was quite different. One may very well agree with the proposition that a person should not be deprived of his property without due process of law, but whose property was the stereo and the stove and the bed? Were they not as much the creditor's property as the debtor's property? What if the debtor had not made a single payment? I do not mean to resurrect the old notion, rejected by the Uniform Commercial Code, that abstract concepts of the passage of title should con-

\footnotetext{
T.

${ }^{22}$ Id. at 96-97. Cf. Lindsey v. Normet, 405 U.S. 56 (1972), which was cited in Fuentes with approval, 407 U.S. at 85 n.15.

${ }^{23} 407$ U.S. at 94-96.

24405 U.S. 174 (1972). But see R. Posner, Economic Analysis or Law (1973).

25 Id. at 187 .
} 
trol. But how does one determine which party's expectations concerning his property are entitled to prejudgment protection? Professor Martin has put the matter this way:

It should be obvious that when the [debtor's] possession is guaranteed, possession is denied to the secured party. Why is possession guaranteed to one party but not to another? Essentially because at the time that the replevin process is invoked, one party is in possession and one is not, so that only one party can be "deprived" of his property in the active sense of that word. In this light, the Fuentes use of due process appears not so much a protection of the individual's property rights against the state ... as mere preservation of the status quo. ${ }^{26}$

I would suggest, perhaps differing only in emphasis, the Supreme Court is moving us away from the most traditional notions of property, notions that speak not only to the physical possession of the property but also to the rightness or legality of that possession. In effect, the Court has given support to a definition of property under which a mere possessor of property has an interest entitled to fourteenth amendment protections, ${ }^{27}$ despite encumbrances on that property and the claims of creditors. Possession has indeed become nine-tenths of the law.

This development is startling, but not completely inconsistent with our legal traditions. In tort law, it has been long recognized that the possessory interest must temporarily prevail in disputed property claim cases until there is some judicial resolution. ${ }^{28}$ Any other rule would allow the more powerful claimant to seize the property, with the attendant possibilities of violence and interference with privacy. More fundamentally, however, the possessory notion of property may be an articulation of a fundamental change in modern societal attitudes and expectations. With the rise of the mass consumer market, and the concomitant extension of credit on a massive scale, ${ }^{29}$ a large proportion of real and personal property is sold on credit. While in the early days of the mass consumer market, debtor-

${ }^{26}$ Martin, supra note 5, at 633. A similar analysis would be applicable to Sniadach if a wage assignment, not garnishment, were involved there. The artificiality of the distinction lends further support to the Fuentes decision.

${ }^{27}$ Cf. O'Neil, Of Justice Delayed and Justice Denied: The Welfare Prior Hearing Cases, 1970 Sup. CT. Rev. 161, 169.

${ }^{28}$ See W. Prosser, Handbook of the Law of Torts $\$ 22$ (4th ed. 1971).

29 See genetally National Commission on Conslimer Finance, Consumer Credit in THE UNITED STITES 5-21 (1972). 
consumers may have felt that their enjoyment of the property was due to the largesse of the creditor, the multiplication of credit transactions and the inherent human need to possess and own and to exercise exclusive control over the immediate home environment - the castle, if you please-has generated expectations of the continued enjoyment of encumbered property. A debtor will say it is "his" house although it is subject to a ninety percent mortgage, just as he will say that it is "his" color television or refrigerator although he has signed a conditional sales contract and has not made a single payment. The proposition that a family does not own anything is too damaging psychologically to countenance, too indicative of rootlessness, too evident of the lack of economic success and too alienative. In Fuentes, the Court did no more than affirm these widespread expectations. The creditor, of course, is the victim of this change in societal and legal attitudes toward property.

The second implication of Fuentes builds on the first. This is the suggestion that the power to authorize nonconsensual changes in the status quo with respect to property, that is, to allow the use of physical force against the debtor or the forceful removal of "his" property without his consent, has been shifted away from the private sector to the public sector. Indeed, while there is no suggestion to this effect in Fuentes, it may be appropriate to assert that only the state can carry out such involuntary transfers of property, that private parties may not enforce such sanctions, even if they have been authorized by the courts.

The obvious rejoinder to this second line of argument takes the following form: While it is true under the facts and circumstances of Fuentes that notice and a hearing were required before the property could be seized, and that as a consequence, the power to effect a change in the status quo was placed in the courts, this was so only because there was state action involved in the case. The power to authorize seizure was never in the hands of creditors since resort to governmental authority, however pro forma, was always required, and repossession was consummated through government agents. Thus, the argument runs, procedural due process is required only when the government itself is involved in the seizure of goods and not when repossession is undertaken pursuant to a private agreement. For it is not so much that power has been taken from private creditors as that any significant governmental intrusion into the process requires adherence to standards of fairness. Fuentes left private reposses- 
sions untouched; and they are entirely permissible, subject to the limitation contained in the Uniform Commercial Code with respect to avoiding breaches of the peace. ${ }^{30}$

\section{State Action}

Under this restrictive view of Fuentes, due process protections should be extended to private repossessions under the Uniform Commercial Code only if the requisite degree of state action can be found. I must confess a degree of ambivalence concerning such an inquiry. On the one hand, whether the Court is concerned with nonconsensual physical interference with possessory interests in property or with more limited notions of governmental fairness, the result in a case testing the constitutionality of private repossession is likely to be articulated, at least in part, in state action terms. The choice of the state action framework, though it does not necessarily dictate a particular underlying theory for invalidating private repossession, is compelled by the traditional view of the fourteenth amendment. On the other hand, the subject of state action is sufficiently murky, the Court's position in any given case sufficiently unpredictable, and the arguments so wholly formalistic and disfunctional, that I fear that a blind emphasis on state action will obfuscate the basic policy considerations. ${ }^{31}$

If the traditional analysis is to be pursued, the Court could easily find state action in that section 9-503 encourages private repossessions, ${ }^{32}$ or that it involves private parties in a public function, ${ }^{33}$ or that legal recognition of private repossessions (e.g., the state's clearing of title to repossessed vehicles) ultimately entwines the state in the repossession. ${ }^{34}$ These issues have been debated by the courts ${ }^{35}$ and commentators. ${ }^{36}$ But the results are

30 Uniform Commercial Code $\$$ 9-503; see Dunham, supra note 5, at 138; White, supra note 2, at 504-08. See also Adams v. Southern Cal. First Nat'l Bank, No. 72-1484 (9th Cir., Oct. 4, 1973).

${ }^{31}$ See, e.g., Adams v. Southern Cal. Nat'l Bank, 492 F.2d 324 (9th Cir. 1974).

32 See Reitman v. Mulkey, 387 U.S. 369 (1967).

33 See Amalgamated Food Employees Union, Local 590 v. Logan Valley Plaza, Inc., 391 U.S. 308 (1968); Evans v. Newton, 382 U.S. 296 (1966); Marsh v. Alabama, 326 U.S. 501 (1946); Smith v. Allwright, 321 U.S. 649 (1944); Hall v. Garson, 430 F.2d 430, 439 (5th Cir. 1970). But see, e.g., Lloyd Corp. v. Tanner, 407 U.S. 551 (1972).

34 See Shelley v. Kraemer, 334 U.S. 1 (1948).

${ }^{35}$ Compare, e.g., Adams v. Southern Cal. First Nat'l Bank, 492 F.2d 324 (9th Cir. 1974) with id. at 338 (Byrne, J., dissenting). See generally cases cited note 7 stpra.

${ }^{36}$ See, e.g., Burke \& Reber, supra note 5, at 12-23 (no state action); Clark, supra note 5, at 329-30 (state action); Clark \& Landers, supra note 2, at 377-383 (state action); Martin, supra note 5, at 638-41 (state action "dubious"); Neth, supra note 5, at 48-63 (no state action); White, supra note 2, at 504-08 (no state action); Comment, supra note 5 (state action). See also McCall, supra note 5. 
inconclusive; the authorities are divided. Indeed, Professor Neth, who has given these issues the most careful analysis, concludes: "While not convincing to me, there is enough in the arguments ... to permit a Supreme Court so inclined to find state action in self-help repossession." ${ }^{37}$

The real inquiry, then, is whether it is wise as a matter of public policy to extend Fuentes to private repossessions, and this essentially involves two questions: Are the additional costs of notice and a hearing outweighed by the economic and other benefits to be derived from them? And are there compelling policy reasons for placing the remedy of repossession in the exclusive domain of the state?

With the notable exception of Professor Dunham, ${ }^{38}$ practicing lawyers and scholars have largely limited themselves to the first question, and I will do no more than suggest the difficulties with both the evidence and the weighing process involved in cost-benefit analysis. The second question framed by the discussion of Fuentes above has received little attention elsewhere, and thus merits a somewhat more detailed treatment. My conclusion is that the state, in an age of mass consumption and consumer credit, should maintain a monopoly over nonconsensual physical interference with the possessory interests of debtors in their property. In fact and in law, neither the power to authorize nor the power to carry out the repossession sanction should be delegable to private parties. This principle, while analogous to the state function theory of state action, is premised more on what due process should affirmatively require of the state than on the safeguards which must be imposed on private parties when they begin to act like the state. ${ }^{39}$ It finds its roots in the necessities of modern policy and not in a simple overview of historical experience. Moreover, the principle does not extend to all unilateral sanctions by a nondefaulting party under a bilateral contract (e.g., acceleration or refusal to convey goods), but only to those which result in the termination of "an existing possession and continuous enjoyment." ${ }^{40}$

\section{Cost-Benefit Analysis}

Perhaps the most thoughtful discussion of the competing economic interests involved in private repossessions appears in a

\footnotetext{
${ }^{37}$ Neth, supra note 5 , at 62.

${ }^{38}$ Dunham, supra note 5.

${ }^{39}$ See generally Tribe, The Supreme Court, 1972 Term-Foreword, Toward a Model of Roles in the Due Process of Life and Law, 87 HARv. L. Rev. 1 (1973).

${ }^{40}$ Dunham, supra note 5 , at 153 .
} 
recent article by Professor James White. ${ }^{41}$ Professor White undertakes a detailed analysis of the costs and benefits to be derived from a requirement of notice and hearing before private seizure of collateral from a debtor. On the cost side, he reaches the following conclusions:

1. Private repossessions of household goods such as refrigerators and washing machines are relatively rare because of the necessity to enter the house and the likelihood that a breach of the peace may result in violation of section 9-503. Private repossessions of automobiles, including both instances of voluntary debtor relinquishment and creditor self-help, are quite common; approximately 960,000 automobiles, representing roughly four percent of all outstanding automobile contracts, are repossessed nationally each year. ${ }^{42}$

2. Given the fact that the average repossession is preceded by thirty or more contacts, ${ }^{43}$ often threatening repossession, the likelihood that a debtor will skip with the automobile simply because a judicial hearing is required is slight. On this basis, the proportion of "skips" likely under private repossession or judicial repossession would appear to be the same.44

3. The per transaction costs of judicial repossession are considerably greater than those of private repossession. Based on

"1 The Abolition of Self-Help Repossession: The Poor Pay Even More, 1973 Wis. L. REv. 503. Professor White's study represents a refinement of earlier work by Professor Robert W. Johnson of the Krannert School of Industrial Administration, Purdue University, which appears in Brief for Permanent Editorial Board for the Uniform Commercial Code as Amicus Curiae, Appendix, Adams v. Southern Cal. First Nat'l Bank, - F.2d (9th Cir. 1973). Professor Johnson's conclusions as to the costs of notice and hearing requirements are higher than are Professor White's. Professor Johnson's analysis was subsequently published, Johnson, Denial of Self-Help Repossession, supra note 5. That published version conflicts in some respects with Professor White's report of Professor Johnson's earlier version. For example, opportunity costs, see text accompanying note 46 infra, in Professor White's earlier report amount to $\$ 24$ for new cars repossessed and $\$ 8$ for used cars, but in the Southern California Law Review version, Professor Johnson lists these costs as $\$ 13$ and $\$ 8$ respectively. Similar adjustments were apparently made in depreciation cost computations. Compare Johnson, Denial of Self-Help Repossession, supra note 5 , at 106 , with White, supra note 2 , at 516 . The figures discussed herein are those accepted by Professor White.

Professor Johnson's published version has been critically examined in Dauer \& - Gilhool, supra note 5. Professor Johnson's rebuttal to this criticism is available as well, see Johnson, $A$ Response, supra note 5.

For a conclusion that "there is no need for the credit market to be unduly concerned with the possible effects of Fuentes and Adams [given the constitutional preclusion of prejudgment self-help repossession]," see Krahmer, Clifford \& Lasley, Fuentes v. Shevin: Due Process and the Consumer, A Legal and Empirical Study, 4 TEx. TECH. L. REv. 23, 62 (1972).

${ }_{42}$ White, supra note 2 , at 513-14.

${ }^{43}$ These include telephone calls, delinquency notices, and personal contacts. Some of these contacts represent communications regarding prior delinquencies, however, not the delinquency that finally precipitates repossession. Id. $515 \mathrm{n} .43$ (citing Johnson, Denial of Self-Help Repossession, supra note 5).

${ }^{4}$ Id. 514-15. 
current experience regarding the frequency of debtor relinquishments before creditor self-help is required, ${ }^{45}$ Professor White estimates that three in five debtors will surrender their automobiles before a hearing takes place. He assumes, however, that none of these voluntary relinquishments will occur prior to the creditor's instituting judicial repossession proceedings. The costs of instituting these proceedings is estimated as $\$ 128$ for an average new car and $\$ 92$ for an average used car. These figures represent two costs not present in private repossessions: legal fees (including court costs) and the losses occasioned by an estimated thirty-day delay in repossessing automobiles. Professor White reasons that if complaints of half the creditors are handled on a production line basis, the lawyer's fee should average out to $\$ 60$ or so for each case, including the costs of filing and service. With respect to the delay, he estimates that the average new car will depreciate $\$ 48$ and the average used car $\$ 26$ during the thirty-day delay, and that opportunity costs will be incurred of $\$ 15$ and $\$ 8$ respectively. By opportunity costs Professor White refers to the dealer's inability to invest the resale value of the repossessed car until after the expiration of the thirty-day period. ${ }^{46}$

For the roughly two in five debtors who refuse to surrender their automobiles prior to the judicial hearing, Professor White adds $\$ 125$, over and above the cost of self-help, to the cost of each repossession. ${ }^{47}$ This represents the estimated costs of proof in default cases. ${ }^{48}$ Totalling the costs of instituting judicial repossession proceedings ${ }^{49}$ for all cases and of proving the two in five default cases, Professor White concludes that the cost of replacing self-help repossession with judicial repossession would be approximately $\$ 143$ million per year. ${ }^{50}$

4. It is unclear whether the creditor will be able to pass on the additional costs of judicial repossession to the debtor or whether he will be compelled to absorb those costs. The assump-

45 See Johnson, Denial of Self-Help Repossession, supra note 5, at 108.

${ }^{46}$ White, supra note 2, at 515-20.

${ }^{17}$ Costs of trying contested cases are not included because those costs would presumably be encountered in a defensive action following a self-help repossession. See Johnson, Denial of Self-Help Repossession, supra note 5, at 99-100.

${ }^{18}$ See note 47 supra. At one point Professor White questions this amount as being too high, because it assumes that a court appearance will be required even in default cases, that is, that the creditor cannot take his default on the basis of an affidavit. White, supra note 2, at 520. Nevertheless, Professor White does not discount the $\$ 125$ figure in his computations. Id. 521 n.54.

${ }^{49}$ Adjustment is also made to account for the difference between opportunity costs in repossessions of new and used cars. Id. 521 n.54.

so Id. $520-22$. 
tion, however, is that the creditor, "by hook or by crook," will find some way to maintain his profit margin. This may take the form of charging higher interest rates or higher prices for goods, excluding high risk debtors from the credit market, or some combination of these alternatives. ${ }^{51}$

Against these costs, Professor White argues that there are very few benefits which attend judicial repossession. Most debtors are actually in default and have more than ample notice that this is the case. The problem of overzealous creditors repossessing goods upon which there is no default is not serious - particularly in the light of the economic costs imposed on creditors by repossession. A related question is how many debtors have valid defenses which they might assert against the creditor. The raising of such defenses may be precluded by the terms of the contract or the holder in due course doctrine, but Professor White does not rest his case on these grounds. Rather, he asserts that instances of such bona fide defenses will be relatively rare. He admits, however, that there is no substantial body of data to support this conclusion. Finally, he asserts that most repossession hearings would be a charade. Even debtors with valid defenses will not appear, because they are ignorant of their rights, fearful of the judicial system, or unable to afford legal counsel. ${ }^{52}$

Balancing these costs and benefits, Professor White concludes that Fuentes should not be extended to private repossessions under section 9-503:

When one has put all the data on the scale and made his best guesses about facts unknown, how does the due process scale tip? Does it call for the elimination of self-help repossession? ... [N]o one can seriously dispute that the removal of self-help repossession will substantially increase car lenders' costs.

What are the benefits to the individual? Surely some debtors who now lose their cars to repossessors will present defenses and save their cars under a prehearing system. . . [But] my guess is that only a handful in a thousand would benefit. . . . Are a few thousand cars worth $\$ 143$ million? I conclude not $\ldots .^{53}$

He distinguishes Fuentes on two cost-benefit grounds: first, the increment in legal costs is not as great in replevin cases since the creditor must file his action in court anyway; and second, re-

${ }^{53}$ Id. $529-30$. 
plevin is often used to repossess household goods which will deteriorate in value only marginally during the thirty-day delay period necessitated by the hearing and notice requirement. ${ }^{54}$

Taken on its own assumption that only economic costs are to be weighed, the balance drawn by Professor White is very much open to question. The most significant flaw is his underestimation of the adaptability of creditors and their lawyers, and state legislatures. To begin with, in the light of the 3 in 5 cases in which the debtor voluntarily surrenders his automobile before the creditor takes self-help action under the current system, it seems likely that the costs of even initiating judicial repossession will be avoided entirely in many cases. ${ }^{55}$ In the cases where the judicial process is invoked, it seems likely, as Professor White assumes, that form complaints will be prepared on a production line basis requiring very little of a lawyer's time. But while he computes that the costs of initiating judicial repossession proceedings could be trimmed in this way to about $\$ 10$, Professor White assumes that half the cases will continue to be "handled in a more conventional fashion at $\$ 75$ to $\$ 100$ per complaint." 56 It seems more reasonable to expect that if costs might be cut so dramatically, a larger percentage of creditors will find it possible to take advantage of streamlined arrangements. Additionally, the legislature might well decide to lower the normal filing feesparticularly if, as Professor White notes, most debtors will not choose to take advantage of their opportunity for a hearing anyway. With respect to delay and the concomitant opportunity and depreciation costs: if the filing process is made simpler and cheaper, a creditor can minimize these costs by serving a notice of hearing and a copy of the complaint early in his series of dunning letters and other contacts. While this might result in the filing of complaints in some cases in which repossession does not become necessary, ${ }^{57}$ experience may well allow the creditor to select with reasonable statistical accuracy those who will likely continue in default.

Where the judicial backlog is substantial, obviously other

S4 Id. 530.

ss See Dauer \& Gilhool, supra note 5, at 125-27; White, supra note 2, at 520. But see Johnson, $A$ Response, supra note 5, at 157-58. Certainly debtors who have equity in the repossessed automobile, or who might be subject to a deficiency judgment, have an incentive to minimize repossession costs in this way.

${ }^{36}$ White, supra note 2, at 518.

${ }^{37}$ Professor White argues that this factor will preclude creditors from considering such a ploy. Id. However, this conclusion is based on Professor White's much higher estimate of the costs of initial filing. Moreover, Professor White fails to consider that the 3 in 5 debtors who voluntarily surrender their automobiles will not necessarily wait until the day before their hearing to do so. The time made up in such cases may serve to balance out other delays. 
statutory solutions may be required. The legislature might also take up the Supreme Court's invitation in Fuentes ${ }^{\mathbf{5 8}}$ to create more efficient, informal and less time-consuming systems for redressing creditor-debtor conflicts, e.g., special consumer courts. Such courts, relying perhaps upon lay advocates, might well reduce the low income consumer's fear of the judicial process and his unwillingness or inability to employ it as well. Legislative innovation might, alternatively, allow a creditor to prove his claim inexpensively by affidavit in the two in five cases in which the debtor defaults. ${ }^{59}$ Thus, given a reasonable response by creditors, lawyers and legislators, Professor White's estimate of the costs of judicial repossession may be greatly exaggerated.

Another basic difficulty with White's analysis is that it draws a sharp distinction between automobiles and other consumer goods, and yet 9-503 would be upheld with respect to all repossessions without reference to this distinction. My impression is that in my home state of Texas at least, refrigerators, furniture, and other household goods and appliances are often subject to private repossession. ${ }^{60}$ Further, I would suggest that if private repossessions of goods other than automobiles are not common elsewhere under the present state of the law, they may become so as the burdens of replevin are increased by the Fuentes decision. In these non-automobile cases, the only additional cost is for legal fees; the opportunity costs and depreciation are usually negligible over a thirty- or sixty-day period. Yet having cast the balance under the due process clause in terms of the typical automobile case, Professor White would nonetheless extend approval of private repossessions to a class of goods in which the creditor's costs are dramatically lower. ${ }^{61}$ I am not suggesting that an issue of constitutional proportions arises from the difference between automobiles and refrigerators; I do mean

${ }^{58} 407$ U.S. at $96-97$.

${ }^{59}$ See notes 292-93 supra \& accompanying text. See also Dauer \& Gilhool, supra note 5, at 125. But see Johnson, $A$ Response, supra note 5 , at 156 . Fuentes does not require a hearing in such cases, 407 U.S. at 92 n.29.

${ }_{60}$ This is true despite the trend, under evolving notions of "breach of the peace," to follow Girard v. Anderson, 219 Iowa 142, 257 N.W. 400 (1934), rather than Cherno v. Bank of Babylon, 54 Misc. 2d 277, 282 N.Y.S.2d 114 (S. Ct. 1967), affd, 29 App. Div. 2d 767, 288 N.Y.S.2d 863 (1968). See generally White, Representing the Low Income Consumer in Repossessions, Resales and Deficiency Judgment Cases, 64 Nw. U.L. Rev. 808, 810-12 (1970); Comment, Non-Judicial Repossession-Reprisal in Need of Reform, 11 B.C. IND. \& Comm. L. Rev. 435, 440-49 (1970).

${ }^{61}$ While it might be expected that the percentage of costs to value in repossessing, say, a color television should be higher than the percentage in an automobile, this is not necessarily true, given the inflated prices frequently attached to such goods, particularly by merchants who sell to high risk consumers. A new color television may well cost more than a used car. 
to say, however, that a cost-benefit study must take into account differences in the likelihood of repossession for different classes of consumer goods.

There are still other factual. questions regarding costs which are not answered and which must be answered in order to complete an economic cost-benefit analysis. ${ }^{62}$ Moreover, even if substantial additional costs are imposed upon the creditor, he may diminish those costs by more carefully screening his debtors. To be sure, this screening may involve some costs of its own, and it is unclear whether the costs of accurately predicting defaults will be substantial. Possibly, however, consumers as a class, or even poor consumers as a class, will not generally be paying significantly higher interest rates or prices; rather, the most marginal consumers will be eliminated from the consumer market through relatively inexpensive changes in the screening process. ${ }^{63}$ In a sense there is a social cost when a discrete group is denied the benefits of color televisions, stereos, and other goods which they cannot afford. On the other hand, is this not the cheapest way to deal with the problem? Court costs, depreciation, attorney's fees and the much discussed losses which a creditor must endure in any transaction in which repossession takes place, would all be eliminated. This assumes, of course, that the screening process is sufficiently accurate so as not to screen out a large group of consumers who would not default, resulting in lost profits exceeding the savings on default avoidance.

Finally, though I have no more empirical proof than Professor White offers, it seems to me likely that breaches of warranty and other defects in the seller's performance are much more likely than he admits. With respect to automobiles, even the most casual reading of consumer magazines, consultation with the service manager at a local dealership, discussions with consumers or common experience should make this clear. If the point is that debtors often cannot assert such defenses against creditors who are holders in due course, or that automobile finance

62 For instance, if state officials are in fact required to execute on the property after judicial repossession, is the cost of repossession by the state less than the cost of a similar private repossession?

${ }^{63}$ Furthermore, to the extent that the costs of repossession are significantly increased, those costs may be most accurately distributed through the mechanism of creditors' seeking deficiency judgments. Unfortunately the deficiency judgment process itself is an expensive way to distribute costs. Furthermore, these costs may be indirectly passed on to the debtor by the use of deflated resale prices in determining the amount of the deficiency judgment. See generally Schuchman, Profit on Default: An Archival Study of Automobile Repossession and Resale, 22 Stan. L. REv. 20 (1969). 
contracts do not permit the right of set-off, this seems to me to be a separate issue. Courts and legislatures are continually required to pass on and re-evaluate the question of what defenses should be available to a debtor; the fact that they may have been restrictive in the past is not conclusive of the desirability of a hearing prior to the repossession of the chattel. More pragmatically, as Professor White notes, ${ }^{64}$ a debtor who remains in possession of the goods may be in a superior bargaining position to negotiate a reduction in price or a basis upon which to retain possession-notwithstanding the technicalities of the code and contract.

Notwithstanding my doubts about the costs that judicial repossession will impose on the creditor, it may well be that Professor White has gotten the better of the argument. It is hardly shocking or novel to assert that some judicial process is more expensive than none, or stated differently, that due process requirements do not create the most efficient system for resolving creditor-debtor disputes. I assume that criminal justice would be much swifter and less expensive if most of the procedural rights afforded criminals were abandoned. Indeed, the only quantifiable cost would be the conviction of one or two defendants in a hundred who would not plead or be found guilty, a cost which would be readily outweighed by the expeditious conviction of the other ninety-eight.

The problem is not simply whether judicial repossession is more expensive than private repossession, or even whether judicial repossession confers economic benefits on debtors as a group equivalent to the additional costs incurred by them; the problem is whether the inevitable additional costs are worth it in the light of the individual rights which are protected..$^{65}$ That is, is protecting the possessory interests of those debtors who are not in default or who have adequate defenses worth the more than $\$ 100$ million (to strike a figure somewhat less than Professor White's) it will require? The due process balance cannot be drawn solely in economic terms; rather, intangible factors must be taken into account, the most important of which is the strength of our ethical belief, grounded in the Constitution, that a person should not be deprived of his possessory interest in property without notice and an opportunity for a hearing. Cost

84 White, supra note 2, at 527-28.

${ }^{65}$ See National Commission on Consumer Finance, sufra note 29, at 30. 
is not irrelevant, but it must be analyzed within the broader framework. ${ }^{66}$

The Fuentes court was well aware of these noneconomic considerations and was at pains to make them clear:

A prior hearing always imposes some costs in time, effort, and expense, and it is often more efficient to dispense with the opportunity for such a hearing. But these rather ordinary costs cannot outweigh the constitutional right. . . . Procedural due process is not intended to promote efficiency or accommodate all possible interests: it is intended to protect the particular interests of the person whose possessions are about to be taken.

... [T]he Constitution recognizes higher values than speed and efficiency. Indeed, one might fairly say of the Bill of Rights in general, and the Due Process Clause in particular, that they were designed to protect the fragile values of a vulnerable citizenry from ... overbearing concern for efficiency and efficacy ... ${ }^{67}$

Without taking the almost absolutist position of $\mathrm{Mr}$. Justice Stewart, do the costs of judicial repossession outweigh the gains? In my view, subjective as it is, the gains in terms of trust in the legal system, perceptions of just treatment, satisfaction of the expectancy interests of American consumers, and monopolization of nonconsensual repossession by the state (to be discussed below), clearly outweigh the debatable additional costs imposed on the creditor and debtor.

Moreover, if the balance of the evidence is unclear and unpersuasive and is likely to remain so, the burden of proof should be placed on the party resisting the application of due process norms. ${ }^{68}$ It has become fashionable these days, in the words of one of my colleagues, Professor Albert Alschuler, to rely on the "significance of statistically insignificant data" to defeat constitutional claims. The world is complex, and the more we study it, the less we seem to know. If the burden of persuasion is placed on the party seeking constitutional protection, if

${ }^{66} \mathrm{It}$ is also crucial in casting the balance here to recognize that it is a system which may be approved, not any particular usage under the system. Thus, the court must be content with its result should usages change or vary, that is, for example, should some creditors find it most efficient to contact their debtors only once before repossession. $C f$. Neth, supra note 5, at 33: "There is evidence that some sellers pervert the system and profit from default and repossession."

67407 U.S. at 90 n.22 (quoting in part Stanley v. Illinois, 405 U.S. 645, 656 (1972)).

${ }^{68}$ But see Martin, supra note 5 , at 630 . 
the argument is that the debtor has not proven that the class he represents or society will necessarily benefit by adherence to constitutional and ethical norms, then those norms become meaningless; the debtor will never be able to prove his case.

\section{The Physical Interference Principle}

Balancing economic costs and benefits is, of course, an effort to determine what procedural process is due debtors prior to interference with their possessory interests in property; and, at least in theory, that question can only follow a conclusion that the state is somehow involved in the interference. But in the self-help repossession cases we are not concerned solely with compelling creditors to follow particular procedures; we are also concerned that they are exercising physical power in the stead of the state. In this light it is significant that the functional effect of Fuentes was to transfer from private creditors to the state the authority to decide whether a repossession would take place prior to final adjudication. Though the decision may be explained on the narrower ground alone, Fuentes also seems to endorse the principle that the state should maintain control over nonconsensual physical interference with property in the possession and control of a party whose claim to that property is contested by another. ${ }^{69}$ Stated somewhat differently, this principle (which I shall call the physical interference principle) holds that the power of the state to interfere physically with the status quo without the consent of property owners may not be delegated in law or fact to private persons. Its justification lies in the strong policies favoring state monopolization of coercive interference with possessory interests in property in an age of mass consumer markets.

As distinguished from traditional fourteenth amendment analysis, the physical interference principle would compel the state to step in to limit private physical interference with possessory rights in property even where the state had not previously been involved. It would clearly prohibit self-help repossession. Thus, it would eliminate the great functional anomaly in the law which would exist if private repossession, though the far greater threat to possessory property rights, were distinguished from replevin on state action grounds and upheld.

${ }^{69}$ Cf. Adams v. Egley, 338 F. Supp. 614 (S.D. Cal. 197\%), rev'd sub. nom. Adams v. Southern Cal. First Nat'l Bank, 492 F.2d 324 (9th Cir. 1974); Dunham, supra note 5, at 153. 
At the same time the physical interference principle is less volatile than the state action arguments currently advanced in the section 9-503 cases. For it would not transform every private contractual relationship, undertaken pursuant to state law or approved by the state judiciary, into state action governed by strict fourteenth amendment standards of fairness and respect for personal and property rights. ${ }^{\mathbf{7 0}}$

The physical interference principle has its origins in admittedly discarded notions of the unconstitutionality of delegations of public police powers to private citizens. But a review of the unconstitutional delegation cases should make clear a few critical distinctions. In a 1912 decision, Eubank $v$. City of Richmond, ${ }^{71}$ the Supreme Court was presented with a local ordinance which provided that the owners of two-thirds of the property on a street could require the municipality to establish a building line for the construction of new edifices. The Court invalidated the ordinance under the due process clause as the conferral of a public power on private property owners. The Court's reasoning was not particularly persuasive; it simply stated, without much discussion, that since there were no standards for the exercise of the power, leaving the possibility that the controlling property owners might act arbitrarily or out of their own selfish interests or individual tastes, the ordinance could not be upheld as an exercise of the power to protect the public health, safety, morals or convenience. After what appears to be an inexplicable variation from this principle in Thomas Cusack Co. v. City of Chicago, ${ }^{72}$ the Court again in Washington ex rel. Seattle Title Trust Co. $v$. Roberge ${ }^{73}$ struck down a local ordinance which it asserted delegated public power to private citizens. In that case, the owners of property within 400 feet of a proposed home for the aged had the effective power to prohibit or allow that land use pursuant to local zoning laws. Finally, in Carter v. Carter Coal Co., ${ }^{74}$ a case involving a constitutional attack on the Bituminous Coal Conservation $\mathrm{Act}^{75}$ enacted during the New Deal, Justice Sutherland, writing for a majority of the Court, fully articulated the rationale of the unconstitutional delegation argument:

${ }^{70} \mathrm{Cf}$. Dunham, supra note 5 , at 153 ; White, supra note 2 , at 506 .

71226 U.S. 137 (1912).

72242 U.S. 526 (1916). See F. Michelman \& T. Sandalow, Government in Urban AREAS 117-24 (1970).

73278 U.S. 116 (1928).

74298 U.S. 238 (1936).

${ }^{75}$ Ch. $824, \S \S 1-23,49$ Stat. 991, repealed, Act of Apr. 26, 1937, ch. 127, § 20(a), 50 Stat. 90. 
[The Bituminous Coal Conservation Act] delegates the power to fix maximum hours of labor to a part of the producers and the miners-namely, "the producers of more than two-thirds of the annual national tonnage production for the preceding calendar year" and "more than one-half of the mine workers employed"; and to producers of more than two-thirds of the district annual tonnage during the preceding calendar year and a majority of the miners, there is delegated the power to fix minimum wages for the district or group of districts. . .

The power conferred upon the majority is, in effect, the power to regulate the affairs of an unwilling minority. This is legislative delegation in its most obnoxious form; for it is not even delegation to an official or an official body, presumptively distinterested, but to private persons whose interests may be and often are adverse to the interests of others in the same business. ... The difference between producing coal and regulating its production is, of course, fundamental. The former is a private activity; the latter is necessarily a governmental function, since, in the very nature of things, one person may not be entrusted with the power to regulate the business of another, and especially of a competitor. And a statute which attempts to confer such power undertakes an intolerable and unconstitutional interference with personal liberty and private property. The delegation is . . . clearly arbitrary, and ... clearly a denial of the rights safeguarded by the due process clause of the Fifth Amendment .... ${ }^{76}$

The position articulated by Justice Sutherland was troublesome. On its face it resurrected notions of the Sovereign as exclusive lawmaker. Grounded in substantive due process, ${ }^{77}$ it evidenced a rejection of principles of representative democracy, principles widely accepted in the society at large. Moreover, the assertion that private lawmaking was unconstitutional seemed to contradict the facts and practicalities of life in a modern industrial society. Moved by these concerns and others, Professor Jaffe, in a classic article, ${ }^{78}$ subjected the Sutherland position to a detailed analysis, and amassed a substantial case that that position was fatally flawed..$^{79}$

76298 U.S. at $310-11$.

77 While the same term might be applied to the role allocation analysis presented here, there is in fact, a real difference. See Tribe, sufra note 39 , at $1,15,32$ passim.

${ }_{78}^{7}$ Jaffe, Law Making by Private Groups, 51 Harv. L. REv. 201 (1937).

79 Less broadly, Carter simply stands for the proposition that the private majority may not take the property of a private minority without the minority's consent. If this is the case, Carter may be more alive than most commentators have indicated. This analysis also 
Professor Jaffe argued that private bodies often enact laws in the sense that they seek to regulate behavior in society. Private associations, labor unions, medical societies and other private groups often promulgate rules which are employed to regulate their members. Contractual relationships, including agreements to allocate property, often take on the character of a private constitution which, within limits, is publicly enforced. Jaffe's conclusions were that private lawmaking pervades American law, that it is not necessarily undesirable, and, indeed, that explicit delegations as in Carter Coal may at times be preferable to tacit de facto delegations.

Participation in lawmaking by private groups under explicit statutory "delegation" does not stand then in absolute contradiction to the traditional process and conditions of law-making; it is not incompatible with the conception of law. It exposes and brings into the open, it institutionalizes a factor in law-making that we have, eagerly in fact, attempted to' obscure. . . . It tends to approach compulsion only where by reason of economic force or special law it is linked with monopoly power or can act upon persons of inferior economic power, whereas the "delegation" supplies this compulsion universally. But it does not follow that the latter is necessarily more oppressive. Tolerated covert monopoliespower exercised indirectly-may be much more difficult to attack or to ameliorate than the edicts of majorities arrived at openly and according to the forms of law. ${ }^{80}$

Additionally Jaffe suggested that in an age of extraordinary demographic growth, technological change, and expanding government, the advantages of decentralization and primary democracy-the education of good citizens and the inculcation of a feeling of responsibility and participation in the affairs of government-may be best promoted and utilized in the lawmaking of private groups. ${ }^{81}$ Thus, in contrast to Justice Sutherland, he applauded the delegation of lawmaking functions to the private sector. ${ }^{82}$

For all the reasons that Professor Jaffe marshalled, the assumption is sound that public power to make law affecting the

suggests a distinction between Carter and repossession cases; in the repossession situation, arguably the debtor has consented to a taking without judicial process. However, if it is conceded that judicial scrutiny of the consent issue itself is required, the difference fades into abstraction.

${ }^{8 n}$ Id. 220-2I.

${ }^{81}$ Id. $202,211-12,251-53$.

${ }^{82}$ Id. 253. 
conduct and behavior of others may be delegated to private persons or bodies. This is a far cry, however, from the problem presented in self-help repossession cases. In such cases the state has not only permitted the parties to determine the law between themselves by way of a contractual undertaking, it has also given private parties the power to impose physical sanctions for the violations of their private laws. It is one thing to allow neighbors to make land use decisions with respect to adjoining property; it is quite another to allow them to authorize and then carry out a physical sanction against a landowner for his failure to abide by their laws, e.g., to tear down a nonconforming structure, even if that sanction might ultimately be ordered by a court. Although the sanctioning power in cases of private repossession is limited in scope and subject to subsequent judicial review, it is nonetheless a substantial nonconsensual interference with possessory property rights which places the burden upon the property owner to secure the return of his property.

The theoretical distinction between the two situations seems clear enough. The delegation of lawmaking power to the private persons affected is necessary in order to achieve the flexible and efficient compromise among the conflicting policies and interests that must go into the making of a rule of general applicability. Such a rationale supports a delegation of the responsibility for deciding, even to the most minute detail, under what facts sanctions should be applied. But it does not support a delegation to private persons of the authority to determine finally what the facts are in a particular case, that is, whether sanctions are authorized within the valid scope of the reigning rule. Such authority, when it involves a sanction of physical interference with possessory property rights, must therefore remain in the state. By the same reasoning, the authority to carry out such sanctions must remain in the state as well. In sum, the repudiation of the doctrine restricting the delegation of public lawmaking power to private persons is hardly a repudiation of the notion that the government should retain a monopoly over the process of applying physical sanctions once the law formation process has been completed.

Moreover, where physical interference with possessory interests in property is concerned, strong policies embedded in common notions of fair process require that the state maintain its monopoly of authority to permit sanctions. To illustrate this point, it is useful to note that even administrative agencies do not 
have the power to seize or destroy property without prior judicial scrutiny, except in emergency situations such as where noxious objects must be destroyed. ${ }^{83}$ As Professor Jaffe has noted,

When the process is the ultimate one of execution, it is customary for the judicial action to precede execution. ... [I]n the regulation of forbidden practices, e.g., unfair labor and trade practices, it has been customary to leave the respondent untouched, at least until the final administrative order and-as with Labor Board orders-even until the entry of a judicial enforcing decree. Recent legislation ... empowers certain agencies, of which the Labor Board is one, to seek a preliminary injunction, a device which once more attests to the ubiquity of the judicial imprimatur before the exercise of official force. ${ }^{84}$

This limitation on administrative agencies is not an attempt to make control of the instrumentalities of enforcement a judicial function (for it is an executive function in any event); rather it is to insure that the judiciary maintains exclusive control of the determination of the legality of the enforcement. ${ }^{85}$

If administrative agencies, despite their broad rulemaking and adjudicative functions, are generally required to seek judicial approval before the imposition of sanctions which interfere with possessory interests, the case is ever so much stronger when private parties seek to authorize and carry out such sanctions by private means. An administrative agency, at least in theory, is a disinterested body seeking to maximize the public good pursuant to its legislative mandate. Private parties, conversely, have a direct and immediate economic stake in the sanctioning decision; and therefore it is unrealistic to expect unbiased decisions, that is, decisions which weigh the competing private property interests and the broader societal implications of the imposition of sanctions. Moreover, administrative agencies are publicly accountable in a way that private decisionmakers are not; only the occasional private lawsuit after the fact stands as a bar to abusive private action.

These arguments for state monopolization of the sanction-

${ }^{83}$ The self-help repossession case would not constitute an emergency exception. See Fuentes v. Shevin, 407 U.S. 67, 90-93 (1972).

${ }_{84} \mathrm{Jaffe}$, The Judicial Enforcement of Administrative Orders, 76 HARv. L. REv. 865-66 (1963). See also Jaffe, The Right to Judicial Review, 71 HARv. L. Rev. 401, 769 (1958) (2 parts). 866 (1963). 
ing process when it involves physical interference with the status quo apply with particular force to private repossessions. Whatever the weaknesses of the judicial process, judges are much more likely to be fair in deciding whether to repossess property. They, unlike the creditors, do not have an economic interest in the decision. In addition, they are required to and are accustomed to abide by procedures designed to insure fairness in the decisionmaking process. Moreover, the typical constraints that would operate to restrict creditor overreaching-the fear of loss of business and goodwill-are generally not significant in any given consumer transaction, and there is little to fear from the disorganized consumer community by way of retaliation. Thus inequality in bargaining power, manifested by adhesive form contracts, is likely to allow the creditor great leeway in making repossession decisions.

Other strong policy reasons dictate that the state must retain its monopoly over the enforcement of sanctions which involve physical intereference with possessory property interests. The arguments concerning this enforcement role, like those concerning the state's authorization role, apply with particular force to the case of self-help repossession. Of course, given Fuentes, the state's monopoly of the enforcement role requires that it maintain the ultimate authorization role as well.

There is a general expectation that the use of force will be monopolized by the state; that even the state's employment of force will be subject to stringent limitations; and that the use of force by private persons, except in extraordinary circumstances, ${ }^{86}$ is illegitimate. Indeed, the Fuentes court, in describing proper prehearing seizures by government authority, specified that in such cases "the State ... kept strict control over its monopoly of legitimate force . . .."87 So far as the enforcement of private rights is concerned, this expectation apparently relies on the principle that only the disinterested state can be depended on to employ force judiciously in promoting private ends.

The Uniform Commercial Code, of course, forbids repossession where it will result in a breach of the peace-at a minimum, where it will result in violence-but this restriction seems clearly insufficient. In the first place, it limits only the kind of force that can be applied; not all physical interference is proscribed. Secondly, as Professor Martin had noted, the Code's

86 See W. Prosser, supra note 28.

87407 U.S. at 91 . 
"restriction is less a certain guaranty that there will be no breach of the peace than a command to the court to invalidate, after the fact, a private repossession that involved breach of the peace." 88 Since after the fact litigation may be rare, and invalidation even rarer, and since the costs of invalidation may be low in economic terms, a rational creditor might well conclude that there is little to fear from violation of the breach of the peace proviso.

Moreover, the likelihood of debtor-initiated violence is less when the state conducts the retaking of the chattel. Often a debtor may not realize that the person taking his property is anything more than a thief or intruder. The repossessor does not have the official trappings of legitimate power-police cars and sirens and uniforms, and even if the private repossessor is known or identified to the debtor, the debtor may very well resist if he thinks the repossession is unwarranted. To be sure, as the average police officer will attest, citizen attacks on policemen are not unknown, but it seems less likely that a citizen would be willing to attack an armed and trained police officer who is clothed with the official order of a court.

A further reason for not allowing creditors to respossess relates to protection of the increasingly respected privacy interest. Nearly all repossessions involve some interference with the privacy interests of the debtor. Intrusion into the house is the most obvious case. But what of opening a debtor's garage door to reclaim an automobile? ${ }^{89}$

Putting aside the case of calculated illegal intrusion, obviously the intrusion of a private agent is most unjust when the repossession is unwarranted. Were a hearing required prior to authorization of the repossession, as would be the case for repossession by a government official, ${ }^{90^{\circ}}$ presumably the intrusion would be avoided. Even when repossession is called for, repossession by a private agent is likely to result in a greater affront to the debtor's privacy interest. The reason for this lies in the private repossessor's reliance on stealth to avoid detection for, if he is detected he must either desist or be guilty of a breach of peace. ${ }^{91}$ The difficulty is two-fold: first, the unwarned debtor

${ }^{88}$ Martin, supra note 5 , at $640-41$.

89 The legality of such entry apparently depends on whether the door was open, locked or closed. See White, supra note 60 , at 811 n.10 (citing cases).

${ }^{90}$ Fuentes, of course, establishes this. See also Blair v. Pitchess, 5 Cal. 3d 258, 272-73, 486 P.2d 1242, 1252-53, 96 Cal. Rptr. 42, 52-53 (1971) (prejudgment seizure of property by county sheriff unconstitutional interference with fourth amendment privacy right where no probable cause shown; apparently requiring showing of probable merit of creditor's claim and probable cause to believe the chattel was in the place to be searched).

${ }^{81}$ See Comment, supra note 60 . 
will be unaware of his exposure and unable to take precautions to protect his privacy; second, the repossessor may increase the scope of his intrusion in order to avoid detection. The typical situation is that of the debtor who awakes to find his car missing-along with many of his personal belongings or papers which were contained in the car. ${ }^{92}$

No doubt this difficulty of preserving debtor privacy in the face of private intrusions to repossess is one element of the general expectation that only the state can legitimately enforce nonconsensual changes in the status quo of possessory property interests. Significantly, the difficulties in both the violence and privacy contexts result not only from conscious misconduct by repossessors; they occur accidentally and unavoidably as well (e.g., creditor initiated violence; taking the papers inside the repossessed car). Even if it could deter intentional misconduct, after-the-fact litigation is no more protection in such cases than was the prospect of damage recoveries for the plaintiffs in Fuentes. ${ }^{93}$ The only certain remedy is monopolization of enforcement by the state.

\section{Conclusion}

The interest of the creditor in private repossession, unhindered by the requirements of notice and hearing prior to the seizure of property, is substantial. There are additional costs imposed by judicial repossession, and creditors may well feel that they have lost their most precious contractual right-the right to preserve their investments without resorting to the complexities imposed by judges and lawyers. ${ }^{94}$ But the toll taken by allowing private repossession is also high; indeed it is greater. The likelihood that debtors who are not in default or who have valid defenses will lose their property is significant; for the creditors, possessed of a vital economic stake in the decision to seize and unconstrained by market forces, may. well be indifferent to the merits of the debtor's position. Most importantly, private repossession sharply undercuts the shared expectation that the debtor's possessory interest in his property may not be infringed

92 See, e.g., Adams v. Southern Cal. First Nat'l Bank, 492 F.2d 324, 327 n.4 (9th Cir. 1974). The creditor may be liable for conversion of personal property inside the car in such a case, however. See Sanders v. General Motors Acceptance Corp., 180 S.C. 138, 185 S.E. 180 (1936).

${ }^{93} \mathrm{See} 407$ U.S. at 81-82.

${ }^{94}$ Creditors apparently feel that the right to take a security interest and to repossess upon default is their single most important remedy. See National Commission on Consumer Finance, supra note 29, at 29-30. 
without his consent or without judicial intervention. Judicial control of the decision to impose the repossession sanction and executive control of the sanction itself are vital to the preservation of society's and the individual's interest in privacy, fairness and nonviolence. The delegation of such power to private persons in our society, under evolving standards of due process, is simply too antithetical to these and other ethical norms to be permitted. 